\title{
Profil Glukosa dan Urea Darah Sapi Bali Jantan yang digemukkan dengan Pakan Komplit yang Mengandung Level Protein Kasar berbeda
}

\author{
Silvester Egi Luan ${ }^{\mathrm{a}}$ Paulus Klau Tahuk ${ }^{\mathrm{b}}$ dan Gerson F. Bira ${ }^{\mathrm{c}}$ \\ ${ }^{a}$ Fakultas Pertanian, Universitas Timor, Kefamenanu, TTU - NTT, 85613, Indonesia, email: egidiusluan2018@gmail.com \\ ${ }^{b}$ Fakultas Pertanian, Universitas Timor, Kefamenanu, TTU - NTT, 85613, Indonesia, email: paulklau@yahoo.co.id \\ ${ }^{c}$ Fakultas Pertanian, Universitas Timor, Kefamenanu, TTU - NTT, 85613, Indonesia, email: gersonbira@yahoo.co.id
}

\section{Article Info}

Article history:

Received 10 Juni 2020

Received in revised form 12 September 2020

Accepted 05 Oktober 2020

DOI:

https://doi.org/10.32938/ja.v5i4.1048

\section{Keywords:}

Glukosa darah

Urea darah

Pakan Komplit

Sapi Bali

\section{Abstrak}

Tujuan dari penelitian ini adalah untuk mengetahui profil glukosa dan urea darah sapi bali jantan yang digemukkan dengan pakan komplit yang mengandung level protein kasar (PK) berbeda. Ternak yang digunakan berupa sapi bali jantan berumur $2-2,5$ tahun dengan berat awal $200 \mathrm{~kg}$. Ransum yang digunakan berupa ransum komplit yang disusun dengan bahan pakan yang terdiri dari: rumput alam, tepung gamal, dedak padi, jagung giling, bran pollard. Metode yang digunakan adalah metode eksperimen menggunakan RAL dengan perlakuan sebagai berikut: $\mathrm{T}_{1}$ : Tepung Rumput $27 \%$ + Tepung Gamal $10 \%$ + Jagung $34 \%$ + Pollard $15 \%$ + Dedak Padi $14 \% \mathrm{~T}_{2}$ : Tepung Rumput $27 \%$ + Tepung Gamal $20 \%$ + Jagung $18 \%$ + Pollard $15 \%$ + Dedak Padi $10 \% \mathrm{~T}_{3}$ : Tepung Rumput $27 \%$ + Tepung Gamal $13 \%+$ Jagung $20 \%$ + Pollard $15 \%$ + Dedak Padi $7 \%$. Variabel yang diukur meliputi kandungan glukosa darah dan urea darah ternak sapi bali jantan dengan waktu pengambilan $0 \mathrm{jam}, 2 \mathrm{jam}, 4 \mathrm{jam}$ dan $6 \mathrm{jam}$ setelah diberi makan. Data yang diperoleh ditabulasi kemudian dianalisis dengan Analysis of Variance (ANOVA) sesuai prosedur rancangan acak lengkap (RAL) menggunakan SPSS versi 19.0. Hasil penelitian menunjukkan bahwa, penggunaan pakan komplit dengan level PK yang berbeda tidak mempengaruhi kadar glukosa dan urea darah sapi bali jantan $(\mathrm{P}>0,05)$. Dimana kadar glukosa darah $(\mathrm{mg} / \mathrm{dL})$ setiap perlakuan adalah T1: 92,392 $\pm 9,779 ; \mathrm{T} 2: 87,448 \pm 7,905 ; \mathrm{T} 3: 93,717$ $\pm 14,969 ;$ Kadar urea darah $(\mathrm{mg} / \mathrm{dL})$ sapi bali jantan masing-masing perlakuan adalah $\mathrm{T} 1: 44,629 \pm 5,663 ; \mathrm{T} 2: 45,473 \pm 4,152 ; \mathrm{T} 3: 44,543$ $\pm 8,343$. Disimpulkan bahwa pemberian pakan komplit dengan level PK $(11 \%, 13 \%, 15 \%)$, dengan energi (TDN $72 \%)$ memberikan pengaruh yang sama untuk semua perlakuan dan menghasilkan kadar glukosa dan urea darah dalam kisaran normal.

\section{Pendahuluan}

Sapi bali merupakan salah satu jenis sapi lokal asli Indonesia yang memiliki potensi untuk dikembangkan sebagai ternak potong karena mempunyai keistimewaan dalam hal reproduksi, persentase karkas yang tinggi, mampu beradaptasi di lingkungan tropis, dan dapat memanfaatkan sumber daya pakan yang berkualitas rendah (Nurjannah, 2014)

Penggemukan merupakan usaha pemeliharaan ternak yang dilakukan untuk menghasilkan ternak yang siap potong untuk menghasilkan daging. Di Nusa Tenggara Timur (NTT), penggemukan sapi bali telah dilakukan secara turun temurun, namun dalam pelaksanaannya masih dihadapkan pada berbagai keterbatasan seperti kurangnya pakan, terutama pada musim kemarau, rendahnya pengetahuan peternak akan tatalaksana pemeliharaan ternak yang baik, serta sistem pemeliharaan ternak tradisonal dan belum berorientasi pasar (Tahuk dan Dethan, 2010). Di antara beberapa faktor yang mempengaruhi usaha penggemukan di NTT tersebut, faktor keterbatasan pakan merupakan salah satu faktor yang sangat penting yang perlu dicarikan jalan keluar pemecahannya. Hal ini dikarenakan aspek pakan berkaitan langsung dengan usaha peningkatan produktivitas ternak yang digemukkan. Menurut Sonjaya (2012), ketersediaan pakan, baik kualitas dan kuantitas yang cukup sangat dibutuhkan untuk mendukung pertumbuhan dan produksi ternak.

Ketersediaan hijauan makanan ternak di NTT yang terbatas dipengaruhi oleh faktor musim, terutama saat kemarau, dimana secara umum Propinsi NTT memiliki dua musim, yaitu musim hujan (basah) berlangsung sangat singkat selama 4 bulan dan musim kemarau (kering) yang berlangsung cukup panjang selama 8 bulan (BPS NTT, 2014). Pada musim hujan hijauan makanan ternak melimpah sehingga pertumbuhan ternak positif, sedangkan pada musim kemarau ketersediaan pakan hijauan sangat kurang dan kualitasnya rendah sehingga pertumbuhan ternak negatif seperti, penurunan bobot badan, pertumbuhan lambat, dan penurunan reproduksi, bahkan tidak jarang dapat menimbulkan kematian (Tahuk dan Dethan, 2010).

Solusi untuk mengatasi kekurangan pakan ternak pada musim kemarau adalah pengembangan teknologi pengolahan pakan dengan pemanfaatan kelimpahan hijauan makanan ternak pada musim hujan seperti rumput lapangan, dan daun gamal yang masih tersedia di lapangan. Bahan pakan tersebut dapat diolah sebagai pakan komplit untuk mengatasi kekurangan pakan pada musim kemarau sehingga produktivitas ternak sapi bali yang digemukkan tetap terjamin.

Pakan komplit merupakan pakan yang cukup mengandung nutrien untuk memenuhi kebutuhan ternak dalam tingkat fisiologis tertentu yang diolah dan diberikan sebagai satu-satunya pakan yang mampu memenuhi kebutuhan hidup pokok dan produksi tanpa tambahan substansi lain kecuali air. Semua bahan pakan tersebut, baik pakan kasar maupun konsentrat dicampur secara homogen menjadi satu (Mide, 2011).

Dalam usaha penggemukan ternak, pemanfaatan pakan yang maksimal oleh sapi bali dapat dilihat dan diketahui melalui pengamatan terhadap parameter darah ternak. Hal ini dikarenakan pakan yang dikonsumsi akan dicerna dan diserap ke dalam aliran darah untuk dialirkan ke seluruh tubuh ternak untuk kelangsungan hidup ternak itu sendiri. Nutrien yang dialirkan melalui darah untuk diserap tersebut dalam bentuk glukosa darah maupun dalam bentuk urea darah. Glukosa darah merupakan salah satu indikator untuk menggambarkan status kecukupan nutrien yang diberikan pada ternak sapi bali jantan selama penggemukan, terutama kecukupan energi. Sebaliknya, urea darah adalah hasil akhir dari proses metabolisme protein dalam tubuh ternak ruminansia yang jika tidak dimanfaatkan oleh tubuh ternak dapat secara maksimal dikeluarkan lewat urin. Urea darah dapat menggambarkan pemanfaatan protein pakan oleh ternak maksimal atau tidak (Tillman et al., 1991). Pemanfaatan pakan komplit oleh petani/peternak di NTT untuk penggemukan sapi bali belum banyak dilakukan.
Akibatnya informasi penggemukkan ternak dan kaitannya dengan status glukosa dan urea darah pada ternak masih kurang. Oleh karena itu, kajian ilmiah yang berkaitan dengan glukosa dan urea darah ini layak dilakukan untuk mengetahui status nutrisi ternak yang digemukkan dengan pemberian pakan komplit.

\section{Metode}

\subsection{Waktu dan Tempat}

Penelitian ini telah dilaksanakan pada tanggal 14 Mei sampai-14 Agustus 2019 di kandang Fakultas Pertanian Universitas Timor. Analisis sampel darah dilakukan di Laboratorium Bio Reproduksi dan Kesehatan Ternak Fakultas Peternakan Universitas Nusa Cendana.

\subsection{Materi Penelitian}

Ternak yang digunakan adalah sapi bali jantan berumur 2-2,5 tahun sejumlah 12 ekor dengan berat badan awal $200 \mathrm{~kg}$. Alat yang digunakan dalam penelitian ini adalah: mesin giling, mesin potong rumput, parang, terpal, timbangan duduk dengan kapasitas $10 \mathrm{~kg}$, timbangan digital kapasitas 2 ton, Jarum hisap, tabung darah dengan lithium heparin, cool box, alat tulis dan kamera. Bahan yang digunakan untuk menyusun ransum komplit terdiri dari rumput alam, tepung gamal, tepung jagung, bran pollard, dedak padi, dan mineral. Kandang yang digunakan adalah kandang individu berbentuk memanjang yang terdiri atas 12 petak dengan ukuran panjang $200 \mathrm{~cm}$, lebar 150 $\mathrm{cm}$, tinggi $200 \mathrm{~cm}$ dan dilengkapi tempat pakan dan tempat minum.

\subsection{Metode Penilitian}

Metode penelitian yang digunakan dalam penelitian ini adalah Rancangan Acak Lengkap (RAL) yang terdiri dari 3 perlakuan dan 4 ulangan sehingga terdapat 12 unit percobaan. Perlakuan yang diberikan adalah sebagai berikut $\mathrm{T}_{1}$ : Tepung Rumput $27 \%$ + Tepung Gamal 10\% + Jagung 34\% + Pollard 15\% Pedak Padi 14\%

$\mathrm{T}_{2}$ : Tepung Rumput 27\% + Tepung Gamal 20\% + Jagung 18\% + Pollard 15\% + Dedak Padi $10 \%$

$\mathrm{T}_{3}$ : Tepung Rumput $27 \%$ + Tepung Gamal 13\% + Jagung 20\% + Pollard 15\% + Dedak Padi 7\%

Pakan komplit (T1) disusun dengan kandungan PK 11\% dan TDN 72\% pakan komplit (T2) disusun dengan kandungan PK 13\% dan TDN 72\% pakan komplit (T3) disusun dengan kandungan PK 15\% dan TDN 72\%

\subsection{Prosedur Penelitian}

Dalam masa persiapan, hal yang dilakukan oleh peneliti adalah menyiapkan kandang dan persiapan lainnya termasuk persiapan pembuatan pakan, pembuatan kandang dengan model permanen yang terdiri dari 12 petak kandang menggunakan papan kayu. Setelah pembuatan kandang selanjutnya dilakukan pemotongan rumput alam, daun gamal, persiapan jagung dan pollard kemudian dibuat pakan komplit. Setelah pengambilan bahan pakan tersebut kemudian dijemur sampai kering dan digiling menggunakan mesin pengiling. gamal dan rumput yang sudah digiling kemudian dicampur dengan tepung jagung dan dedak sesuai perlakuan serta diberikan 2 kali dalam sehari yakni pagi dan sore hari sebanyak 3\% BK dari berat badan ternak. Air minum diberikan secara ad libitum menggunakan ember plastik yang diletakan disamping tempat makan.

\subsection{Prosedur Pengambilan Darah}

Koleksi darah dilakukan pada minggu terakhir penelitian melalui vena jugularis, menggunakan jarum serta tabung darah berukuran $3 \mathrm{ml}$ yang beris lithium heparin. Pengambilan darah sapi sebanyak 4 kali/ekor, dengan waktu 
pengambilan yaitu: 0 jam sebelum diberi makan (puasa), selanjutnya 2 jam, 4 jam dan 6 jam setelah diberi makan. Darah yang ditampung pada tabung, kemudian disimpan pada cool box, untuk selanjutnya dilakukan analisis darah terhadap kandungan glukosa dan urea darah di laboratorium.

\begin{tabular}{lccccc}
\multicolumn{6}{l}{ Tabel 1. Kandungan nutrisi bahan } \\
$\begin{array}{l}\text { Bahan } \\
\text { Pakan }\end{array}$ & $\begin{array}{c}\text { Rumput } \\
\text { Lapangan }\end{array}$ & $\begin{array}{c}\text { Daun } \\
\text { Gamal }\end{array}$ & $\begin{array}{c}\text { Jagung } \\
\text { Giling }\end{array}$ & $\begin{array}{c}\text { Bran } \\
\text { Pollard }\end{array}$ & $\begin{array}{c}\text { Dedak } \\
\text { Padi }\end{array}$ \\
\hline BK (\%) & 88,986 & 85,260 & 85,950 & 87,165 & 89,691 \\
BO (\%) & 77,388 & 76,397 & 83,012 & 82,663 & 77,062 \\
PK (\%) & 5,318 & 21,377 & 9,609 & 16,648 & 10,444 \\
LK (\%) & 0,805 & 3,403 & 8,967 & 3,329 & 8,181 \\
SK (\% BK) & 28,221 & 11,137 & 3,059 & 6,902 & 15,103 \\
CHO (\% BK) & 71,266 & 51,617 & 64,437 & 62,685 & 58,436 \\
BETN (\% BK) & 43,045 & 40,479 & 61,378 & 55,784 & $43,334-$
\end{tabular}

$\mathrm{GE}$

$\begin{array}{llllll}-(\mathrm{Mj} / \mathrm{kg} \mathrm{BK}) & 13,892 & 15,272 & 16,535 & 16,015 & 15432\end{array}$

$\begin{array}{llllll}-(\mathrm{Kkal} / \mathrm{kg} \mathrm{BK}) & 3307,69 & 3636,16 & 3973,01 & 3813,19 & 3674,28\end{array}$

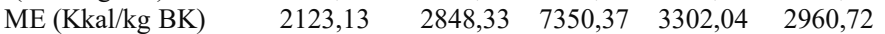

Ket :BK : Bahan Kering; BO: Bahan Organik; PK : Protein Kasar ;LK: Lemak Kasar;SK : Serat Kasar;CHO : Karbohidrat;BETN : Bahan Ekstrak Tanpa Nitrogen ;TDN: Total Digestible Nutrien;GE: Gross energy ;ME: Metabolisme energi. Sumber: Hasil analisis Laboratorium kimia pakan Fakultas Peternakan Universitas Nusa Cendana (2019).

\subsection{Variabel Penelitian}

\section{Glukosa Darah}

Prosedur analisis glukosa darah di Laboratorium Bio Reproduksi Dan Kesehatan Ternak Fakultas Peternakan Universitas Nusa Cendana sebagai berikut: Pemeriksaan glukosa darah dengan spektrofotometer sesuai petunjuk analisis glukosa darah. Siapkan tabung sesuai banyak sampel, kemudian diisi dengan reagen glukosa $5 \mathrm{ml}$ serta 1 tabung berisi reagen standar. Tambahkan 0,02 sampel plasma darah kedalam tabung berisi reagen glukosa kemudian diamkan selama 20 menit. Masukan reagen standar kedalam spektrofotometer yang telah disambungkan dengan layar monitor. Kemudian bacalah absorban larutan standar pada panjang gelombang $546 \mathrm{~nm}$. Hal yang sama juga dilakukan pada sampel yang telah didiamkan selama 20 menit kemudian bacalah absorban larutan standar pada panjang gelombang yang sama. Perhitungan kadar glukosa darah dengan rumus:

(Abs. Sampel/Abs. Standar) X $100 \mathrm{Mg} / \mathrm{dl}$.

\section{Urea Darah}

Pemeriksaan urea darah dengan spektrofotometer sesuai dengan petunjuk analisis urea darah. Siapkan tabung sesuai banyak sampel, kemudian diisi dengan reagen urea $5 \mathrm{ml}$ serta 1 tabung berisi reagen standar. Tambahkan $0,02 \mathrm{ml}$ sampel plasma darah kedalam tabung berisi reagen-reagen kemudian didiamkan selama 20 menit. Masukan reagen standar kedalam spektrofotometer yang telah disambungkan dengan layar monitor. Bacalah absorban larutan standar pada panjang gelombang $546 \mathrm{~nm}$. Hal yang sama juga dilakukan pada sampel yang telah didiamkan selama 20 menit kemudian bacalah absorban larutan standar pada panjang gelombang yang sama. Perhitungan kadar urea darah dengan rumus

\section{(Abs. Sampel/Abs. Standar) X $50 \mathrm{Mg} / \mathrm{dl}$.}

\subsection{Analisis Data}

Data yang diperoleh ditabulasi kemudian dianalisis dengan Analysis of Variance (ANOVA) sesuai prosedur rancangan acak lengkap (RAL) menggunakan SPSS versi 19.0.

\section{Hasil dan Pembahasan}

\subsection{Pengaruh Perlakuan Terhadap Kandungan Glukosa Darah Ternak} Sapi Bali Jantan Percobaan

Glukosa adalah salah satu substrat metabolisme utama yang diperlukan tubuh untuk memenuhi kebutuhan energi bagi ternak ruminansia dalam melaksanakan fungsi produksi dan reproduksi ternak. Hasil analisis laboratorium terhadap kandungan glukosa darah ternak sapi bali jantan yang diberikan pakan komplit dengan level PK yang berbeda dapat dilihat pada Tabel 2.

Hasil penelitian pada Tabel 2 terlihat bahwa kadar glukosa darah ternak sapi jantan yang diberikan pakan komplit dengan level PK yang berbeda, masingmasing pada $0,2,4,6$ jam untuk perlakuan T1 adalah sebesar $120,840 \pm 14,270$; $76,285 \pm 7,017 ; 88,218 \pm 8,638$; dan $84,228 \pm 9,190 \mathrm{mg} / \mathrm{dL}$ atau rata-rata sebesar $92,392 \pm 9,779 \mathrm{mg} / \mathrm{dL}$. Kandungan glukosa darah perlakuan T2 pada pengamatan 0 jam sebelum makan sampai 6 jam setelah makan adalah 96, $080 \pm 10,752$; $78,503 \pm 7,081 ; 92,970 \pm 7,903$ dan $82,240 \pm 5,882 \mathrm{mg} / \mathrm{dL}$ atau rata-rata sebesar $87,448 \pm 7,905 \mathrm{mg} / \mathrm{dL}$; dan perlakuan $\mathrm{T} 3$ pada waktupengamatan yang sama sebesar 106,380 $\pm 19,770 ; 84,055 \pm 11,044 ; 99,255 \pm 13,009 ;$ dan 85, $178 \pm$ $16,054 \mathrm{mg} / \mathrm{dL}$ atau rata-rata $93,717 \pm 14,969 \mathrm{mg} / \mathrm{dL}$.

Hasil analisis statistik menunjukkan bahwa kadar glukosa pada ternak sap bali jantan yang diberikan pakan komplit dengan level PK yang berbeda berpengaruh tidak nyata. Kadar glukosa darah tiap ternak sapi bali jantan pada masing-masing perlakuan dalam penelitian ini cukup berfluktuasi. Rata-rata glukosa darah dari setiap perlakuan menunjukkan konsentrasi tertinggi pada 0 jam sebelum pemberian pakan (puasa) selanjutnya menurun pada 2 jam setelah pemberian pakan dan mencapai puncak tertinggi setelah 4 jam pemberian pakan, dan kembali menurun lagi pada 6 jam setelah pemberian pakan.

Tabel 2. Kandungan glukosa darah ternak sapi bali jantan percobaan dengan pemberian pakan komplit dengan level PK yang berbeda

\begin{tabular}{cccc} 
Glukosa Darah & \multicolumn{3}{c}{ Perlakuan } \\
\cline { 2 - 4 }$(\mathrm{mg} / \mathrm{dL})$ & $\mathrm{T} 1(11 \% \mathrm{PK})$ & $\mathrm{T} 2(13 \% \mathrm{PK})$ & $\mathrm{T} 3(15 \% \mathrm{PK})$ \\
\hline 0 Jam & $120,840 \pm 14,270$ & $96.080 \pm 10,752$ & $106,380 \pm 19,770$ \\
2 Jam & $76,285 \pm 7,017$ & $78,503 \pm 7,081$ & $84,055 \pm 11,044$ \\
4 Jam & $88,213 \pm 8,638$ & $92,970 \pm 7,903$ & $99,255 \pm 13,009$ \\
6 Jam & $84,228 \pm 9,190$ & $82,240 \pm 5,882$ & $85,178 \pm 16,054$ \\
\hline Rata-rata & $92,392 \pm 9,779$ & $87,448 \pm 7,905$ & $93,717 \pm 14,969$ \\
\hline
\end{tabular}

Tingginya glukosa darah pada 0 jam sebelum pemberian pakan (puasa) dalam penelitan ini diduga karena proses pembentukan glukosa dari glikogen meningkat, selain itu diduga karena hijauan yang digunakan dalam penelitian ini berupa rumput lapangan yang memiliki serat kasar (SK) tinggi sehingga proses pencernaan dalam rumen lebih lambat. Hal ini akan berdampak pada produks asam lemak terbang (VFA) terutama asam propinate terus berkelanjutan untuk sintesis glukosa. Menurut Purbowati et al. (2004), peningkatan kadar glukosa darah dari sebelum makan dan sesudah makan karena adanya rangsangan pelepasan hormon insulin, dan 2 jam setelah dikonsumsi pakan glukosa darah mengalami penurunan. Sebaliknya, konsentrasi meningkat pada 4 jam setelah pemberian pakan dan akan menurun lagi pada 6 jam setelah pemberian pakan komplit. Hal ini diduga karena kecernaan pakan komplit sudah optimal. Selain kecernaan, faktor yang mempengaruhi kadar glukosa darah adalah jumlah ransum yang dikonsumsi (Rahayu et al., 2017). Nilai glukosa darah berhubungan erat dengan konsumsi energi, jika energi rendah maka glukosa darah juga rendah, sebaliknya konsumsi energi tinggi maka glukosa darah juga tinggi (Bondi, 1987; Church dan Pond, 1988).

Kandungan glukosa darah yang tidak berbeda ini diduga disebabkan oleh kesamaan konsumsi pakan terutama pada suplai karbohidrat untuk pembentukan glukosa darah yang relatif sama. Namun demikian, kadar glukosa darah pada penelitian ini tergolong normal. Mitruka et al. (1977) melaporkan bahwa kisaran normal kadar glukosa darah ternak sapi bervariasi antara 43-100 mg/dL. Normalnya kadar glukosa darah ini selain karena faktor energi yang disuplai dari pakan yang dikonsumsi, juga karena adanya mekanisme kontrol oleh hormon insulin dan glukagon yang mengatur keseimbangan kandungan glukosa darah pada ternak. Perubahan kadar glukosa antar waktu 0, 2, 4 dan 6 jam diduga disebabkan oleh aktivitas hormon insulin yang bekerja menstabilkan kadar glukosa darah dengan cara mendorong glukosa darah menjadi glikogen hati dan otot. Lehninger (1994) menjelaskan bahwa bila kadar glukosa darah naik, hormon insulin akan meningkat sehingga akan mempercepat masuknya glukosa ke dalam hati dan otot dimana glukosa akan diubah menjadi glikogen. Menurut Purbowati et al.(2004), peningkatan kadar glukosa darah dari sebelum dan sesudah makan karena adanya rangsangan pelepasan hormon insulin. Glukosa darah ternak ruminansia tidak hanya berasal dari sakarida pakan tetapi dari VFA yang berasal dari pencernaan serat kasar atau karbohidrat difermentasi oleh mikroba rumen menjadi VFA (Manu, 2007 dikutip Tahuk et al., 2008). Dikatakan lebih lanjut bahwa 40-60\% glukosa darah berasal dari propionat, $20 \%$ dari protein dan sisanya berasal dari VFA rantai cabang, asam laktat dan gliserol. Asam amino dapat menyumbang glukosa sebanyak $11-30 \%$ dari total glukosa dimana substrat yang paling penting adalah alanin, glutamate dan aspartat. Hormon juga dapat mempengaruhi kadar glukosa darah. Pengaturan konsentrasi glukosa darah dipengaruhi oleh hormon insulin dan glukagon yang disekresikan dalam pancreas dan selanjutnya ke dalam darah. Insulin merupakan hormon peptida yang disekresikan oleh sel beta pankreas. Fungsi insulin yaitu mengatur kadar normal glukosa darah (Wilcox, 2005).

Hasil penelitian ini lebih tinggi bila dibandingkan dengan laporan hasil penelitian Suwasono et al. (2013) pada sapi jawa jantan dengan kadar glukosa darah pada 0 jam (sebelum makan) adalah 53,54 mg/dL, sedangkan pada 3, 6 dan 9 jam setelah pemberian pakan masing-masing adalah 51,$11 ; 63,61$; dan 54,93 $\mathrm{mg} / \mathrm{dL}$. Kadar glukosa darah hasil pengamatan juga lebih tinggi dari hasil penelitian Tahuk et al. (2017) yang meneliti tentang profil glukosa dan urea darah pada sapi bali jantan pada penggemukkan dengan hijauan di peternakan rakyat dengan rerata kadar glukosa darah sebelum pemberian pakan ( 0 jam) adalah $59,07 \mathrm{mg} / \mathrm{dl}$; dan pada 2,4 dan 6 jam setelah pemberian pakan masing- masing adalah 57,$29 ; 56,94$ dan $61,20 \mathrm{mg} / \mathrm{dL}$ atau rerata $58,62 \mathrm{md} / \mathrm{dL}$. Perbedaan hasil penelitian dengan kedua penelitian tersebut diduga lebih dipengaruhi oleh perbedaan pakan yang diujicobakan. Faktor pakan terutama konsumsi energi sangat menentukan tinggi rendahnya kadar glukosa darah. Dalam laporanlaporan di atas kadar glukosa darah kedua peneliti yang dihasilkan lebih rendah karena hanya menggunakan hijauan $100 \%$ tanpa konsentrat dalam pakan sehingga berdampak pula pada rendahnya karbohidrat mudah tercerna yang dikonsumsi ternak. Konsentrat merupakan sumber energi yang mudah tercerna, sehingga produksi asam propionat yang merupakan prekursor glukosa akan lebih tinggi. Apabila pakan yang diberikan telah sesuai kebutuhan akan menghasilkan kandungan metabolik yang normal namun apabila pakan yang diberikan kurang maka nilai metabolik darah akan rendah (Ogata, 2010).

Dampak glukosa darah pada ternak seperti ternak kekurangan glukosa secara drastis didalam darah dapat menimbulkan kondisi sakit yang disebut 
hipoglikemia. Hipoglikemia atau hiperketonemia yang sering disebut ketosis dapat berlangsung secara sub klinis dan bisa berkembang menjadi klinis. Sapi yang mengalami hiperketonemia nafsu makan menurun, dan bila berlangsung lama menyebabkan kerusakan hati yang permanen dan mengalami ketosis kronik. Apabila ternak memiliki glukosa darah cukup ternak akan memiliki pertumbuhan yang normal seperti nafsu makan tetap meningkat, bebas dari penyakit hipoglikemia (Ayuningsih, 2007).

\subsection{Pengaruh Perlakuan Terhadap Kandungan Urea Darah Ternak Sap Bali Jantan Percobaan}

Urea darah merupakan fungsi dari penyerapan amonia dari rumen dan efisiensi penggunaan protein pada tingkat jaringan (Rusdi, 2006) .Hasil analisis laboratorium terhadap kandungan urea darah ternak sapi bali jantan yang diberikan pakan komplit dengan level PK yang berbeda dapa dilihat pada Tabel 3 .

Tabel 3. Kandungan urea darah ternak sapi bali jantan percobaan dengan pemberian pakan komplit dengan level PK yang berbeda

\begin{tabular}{cccc}
\hline \multirow{2}{*}{$\begin{array}{c}\text { Urea Darah } \\
(\mathrm{mg} / \mathrm{dL})\end{array}$} & $\mathrm{T} 1(11 \% \mathrm{PK})$ & $\mathrm{T} 2(13 \% \mathrm{PK})$ & $\mathrm{T} 3(15 \% \mathrm{PK})$ \\
\cline { 2 - 4 } 0 Jam & $38,168 \pm 5,627$ & $32,083 \pm 2,868$ & $37,298 \pm 9,670$ \\
2 Jam & $47,528 \pm 5,960$ & $47,153 \pm 5,883$ & $44,988 \pm 8,187$ \\
4 Jam & $51,935 \pm 3,687$ & $56,577 \pm 4,510$ & $52,798 \pm 10,538$ \\
6 Jam & $40,883 \pm 7,377$ & $46,077 \pm 3,347$ & $43,088 \pm 4,978$ \\
\hline Rata-rata & $44,629 \pm 5,663$ & $45,473 \pm 4,152$ & $44,543 \pm 8,343$ \\
\hline
\end{tabular}

Pada Tabel 3 terlihat bahwa kandungan kadar urea darah ternak sapi bali jantan yang diberikan pakan komplit dengan level PK yang berbeda masingmasing pada kisaran 0 sebelum makan, dan 2, 4, 6 jam setelah makan untuk perlakuan T1 adalah sebesar 38,168 $\pm 5,627 ; 47,528 \pm 5,960 ; 51,935 \pm 3,687$; dan $40,883 \pm 7,373 \mathrm{mg} / \mathrm{dL}$ atau rata-rata sebesar 44,629 $\pm 5,663 \mathrm{mg} / \mathrm{dL}$. Untuk perlakuan T2 pada waktu pengamatan yang sama adalah sebesar $32,083 \pm 2,868$; $47,153 \pm 5,883 ; 56,577 \pm 4,510$ dan $46,077 \pm 3,347 \mathrm{mg} / \mathrm{dL}$ atau rata-rata sebesa $45,473 \pm 4,152 \mathrm{mg} / \mathrm{dL}$; dan untuk perlakuan T3 adalah sebesar 37,298 \pm 9,670; $44,988 \pm 8,187 ; 52,798 \pm 10,538 ;$ dan $43,088 \pm 4,978 \mathrm{mg} / \mathrm{dL}$ atau rata-rata $44,543 \pm 8,343 \mathrm{mg} / \mathrm{dL}$. Hasil analisis statistik menunjukkan bahwa kadar urea darah pada ternak sapi jantan yang diberi pakan komplit dengan level PK yang berbeda berpengaruh tidak nyata. Kadar urea darah tiap ternak sapi jantan pada masing-masing perlakuan dalam penelitian ini cenderung terus meningkat, yang diawali dari 0 jam (sebelum pemberian pakan) dan mencapai puncak tertinggi setelah 4 jam pemberian pakan, yang selanjutnya menurun pada 6 jam setelah pemberian pakan.

Kadar urea darah dari perlakuan T1; T2 dan T3 berada dalam kisaran normal. Menurut pendapat Hungate (1966), kisaran normal urea darah untuk ternak sapi adalah berkisar antara $26,6-56,7 \mathrm{mg} / \mathrm{dL}$. Bila urea darah lebih tinggi dari kisaran normal, maka absorbsi amonia yang dibawa ke hati akan berlebihan sehingga perombakan menjadi urea kalah cepat. Dengan demikian kadar urea dan amonia di dalam peredaran darah perifer menjadi naik dan ternak memperlihatkan gejala keracunan yang akhirnya dapat menyebabkan kematian (Ranjhan, 1981). Sebaliknya, jika urea darah rendah ternak akan mengalami pertumbuhan lambat. Rendahnya kadar urea darah menguntungkan jika dilihat dari efisiensi penggunaan energi.

Tingginya kadar urea pada penelitian ini diduga berkaitan dengan sumber pakan yang diberikan. Hal ini sesuai pendapat Riis (1983), bahwa urea darah dipengaruhi oleh pakan karena sebagian besar urea diperoleh dari penguraian protein yang berasal dari pakan. Pada ternak yang mempunyai asupan protein tinggi, sebagian besar protein tersebut akan mengalami fermentasi di rumen, sehingga berdampak peningkatan kadar urea dalam darah di atas dalam keadaan normal.

Kadar urea pada penelitian lebih tinggi dibandingkan dengan hasil penelitian Tahuk et al. (2017), yang memperoleh kadar urea darah masingmasinguntuk 0, 2, 4 dan 6 jam adalah 23,658;23,793;24,158 dan 24,812 mg/dl pada sapi bali jantan pada penggemukan dengan hijauan di peternakan rakyat. Perbedaan hasil penelitian ini diduga lebih pada perbedaan pakan yang diujicobakan. Pada laporan penelitian Tahuk et al. (2017), urea darah yang diperoleh lebih rendah karena hanya menggunakan hijauan 100\% tanpa konsentrat dalam pakan sehingga berdampak pula pada rendahnya karbohidrat mudah tercerna yang dikonsumsi ternak.

Menurut Soeparno (2005), protein yang masuk ke dalam tubuh akan mengalami tiga kemungkinan yaitu dicerna oleh mikroba rumen, mengalami degradasi, dan diserap melalui dinding rumen lalu dibawah menuju hati, diubah menjadi urea dan kemungkinan lain yaitu protein melalui rumen tanpa mengalami degradasi. Pada ternak muda protein yang diabsorbsi dimanfaatkan oleh tubuh ternak untuk pertumbuhan, mengganti sel-sel yang rusak dan pada kondisi tertentu akan diubah menjadi energi.

\section{Simpulan}

Berdasarkan hasil penelitian yang telah dilakukan, maka dapa disimpulkan bahwa pemberian pakan komplit dengan level PK $(11 \%, 13 \%$, $15 \%$ ), dengan energi (TDN 72\%) memberikan pengaruh yang sama untuk semua perlakuan dan menghasilkan kadar glukosa dan urea darah dalam kisaran normal.
Pustaka

Ayuningsih, B. 2017. Pengaruh Nutrisi Terhadap Timbulnya Ketosis Pada Sapi Laktasi.Universitas Padjajaran. Bandung.

Badan Pusat Statistik.. 2014. Nusa Tenggara Timur dalam Angka. Provinsi Nusa Tenggara Timur.

Bondi, A.A. 1987. Animal Nutrition. John Wiley \& Sons, Chichester.

Church, C.D. and Pond, V.G. 1988. Macro-and micro-minerals. In: Basic Animal Nutrition and Feeding. 3rd ed. John Wiley and Son Inc., USA.

Hungate, R.E. 1966. The rumen and itsmicrobes. Academic Press, New York and London.

Lehninger, A.L. 1994. Dasar-dasar Biokimia.Jilid 3. Penerbit Erlangga, Jakarta.

Mide, M.Z, 2011. Penampilan Sapi Bali Jantan Muda yang Diberikan Pakan Komplit. Skripsi. Fakultas Peternakan Universitas Hasanuddin, Makassar.

Mitruka, B. M., H. M. Rawnsley, and B.V. Vadehra. 1977. Clinical Biochemica and Hematological Reference Values in Normal Experimental Animals. Masson Publishing, Inc., New York.

Nurjannah.2014. Kecernaan Nutrien Ransum Sapi Bali Dengan Penambahan Sabun Kalsium Minyak Kedelai Secara In Vitro. Skripsi. Institut Pertanian Bogor.

Ogata, Katsuhiko. 2010. Modern Control Engineering fifth edition. New York: Prentice-Hall, Inc.

Purbowati, E., E. Baliarti dan S.P.S. Budhi. 2004. Tampilan Glukosa, NH3 dan urea darah domba yang digemukan secara feedlot dengan pakan dasar dan level kosentrat yang berbeda. J. Pengemb. Pet. Trop. 1: 81-85.

Rahayu Ventu Rini,Resty Gessya Ariani, Ikhsan.2017. Laporan praktikum Biokimia Kllinis, Kadar Glukosa Darah. Departamen Biokimia, Fakultas Matematika, Ilmu pengetahuan Alam, Institut Pertanian Bogor. Bogor.

Ranjhan, S.K. 1981. Animal Nutrition in Tropics.Second Revised Edition.Vikas Publishing House. PVT LTD, New Delhi.

Riis, P. M. 1983. Dynamic Biochemistry of Animal Production. Elsevier, New York.

Rusdi, 2006. Dinamika Protein Pada Ruminansia.Tandulako University Press Palu.

Soeparno. 2005. Ilmu dan teknologi daging cetakan keempat. Gadjah Mada University Press, Yogyakarta.

Sonjaya. H. 2012. Dasar Fisiologi Ternak. IPB. Press. Bogor

Suwasono P., A. Purnomoadi dan S. Dartosukarno. 2013. Kadar Hematokrit, Glukosa dan Urea Darah Sapi Jawa Yang Diberi Pakan Konsentrat Dengan Tingkat Yang Berbeda. J. Animal Agriculture, 2(4): 37-44.

Tahuk, P.K, A.A. Dethan dan S. Sio., 2017. Profil Glukosa dan Urea Darah Sapi Bali Jantan pada Penggemukan dengan Hijauan (Greenloy Fettening) di Peternakan Rakyat. J. Agripet, 17 (2) : 104-111.

Tahuk, P.K. and A.A. Dethan, 2010. Performance of Bali bull in greenlot fattening byfarmers when rainy season in Timor island. Journal of the Indonesian Tropical Animal Agriculture, 35(4):257-261.

Tahuk, P.K; Endang Baliarti, dan Hari Hartadi 2008. Kinerja Kambing Bligon Pada Penggemukan Dengan Level Protein Pakan Berbeda.Buletin Peternakan, 32(2):121-135.

Tillman, A.D., H..Hartadi, S. Reksohadiprodjo, S. Prawirokusumo, dan S. Lebdosoekojo. 1991. Ilmu Makanan Ternak Dasar. Cetakan ke-4.Gajah Mada University Press.Yogyakarta.

Wilcox.G. 2005. Insulin and insulin resistance clinical biochemistry review: 26 , $19-39$. 